\title{
Kearifan Lokal Masyarakat sebagai Upaya Konservasi Hutan Pelawan di Kabupaten Bangka Tengah, Bangka Belitung
}

\author{
Henri $^{1}$, Luchman Hakim² ${ }^{2}$ dan Jati Batoro ${ }^{2}$ \\ ${ }^{1}$ Jurusan Biologi, Universitas Bangka Belitung, Bangka 33172; e-mail: biology.henry@gmail.com \\ 2Jurusan Biologi, Universitas Brawijaya, Malang 65145
}

\begin{abstract}
ABSTRAK
Penurunan keanekaragaman hayati umumnya disebabkan oleh adanya degradasi sumberdaya hayati dan kurangnya upaya konservasi. Oleh karena itu, salah satu upaya konservasi sumberdaya alam dapat dilakukan dengan mengintegrasikan kearifan lokal masyarakat dalam melestarikan lingkungan yang berkelanjutan. Penelitian ini dilaksanakan pada bulan Oktober 2016-Februari 2017 di Hutan Pelawan, Kabupaten Bangka Tengah, Bangka Belitung. Metode penelitian yang digunakan adalah observasi, wawancara secara mendalam (In-depth Interview) dan FGD (Focus Group Discussion) yang terbagi menjadi small group discussion dan final group discussion. Hasil penelitian menunjukkan bahwa sejarah penamaan Hutan Pelawan berasal dari pohon pelawan (Tristaniopsis merguensis Griff.) yang mendominasi kawasan hutan tersebut. Hutan ini mengalami pro dan kontra sebelum ditetapkan sebagai kawasan Taman Keanekaragaman Hayati (Taman Kehati) Kabupaten Bangka Tengah. Pada saat ini, kondisi hutan tersebut telah memiliki tiga fungsi utama yaitu: konservasi sumberdaya hayati, pembangunan berkelanjutan, dan logistic support (penelitian, pendidikan, dan monitoring). Kearifan lokal masyarakat yang masih terjaga dan berkaitan langsung dengan upaya konservasi sumberdaya alam Hutan Pelawan masih dapat ditemukan seperti tradisi musung madu dengan cara membuat sunggau untuk mendapatkan hasil berupa air madu dari Apis dorsata (madu liar). Selain itu, masyarakat juga masih mempercayai tentang mitos tumbuh jamur Pelawan (Heimioporus sp.) yang hanya dapat tumbuh pada inang pohon T. merguensis disaat adanya hujan petir. Oleh karena itu, perlunya mengintegrasikan kearifan lokal masyarakat dalam mendukung upaya konservasi dengan merevitalisasi dan mereaktualisasi kearifan lokal tersebut yang diberi dasar hukum sebagai dasar kekuatan masyarakat, serta perlunya kajian penelitian yang ilmiah dalam mendukung kearifan lokal sebagai upaya konservasi lingkungan sehingga memberi dampak positif bagi kehidupan masyarakat tersebut.
\end{abstract}

Kata kunci: Kearifan lokal, sumberdaya hayati, konservasi, hutan pelawan.

\begin{abstract}
The decrease in biodiversity is generally caused by the degradation of biological resources and the lack of conservation efforts. Therefore, one of nature resource conservation efforts can be done by integrating local wisdom of society in preserving environment sustainable. This research was conducted on October 2016-February 2017 in Pelawan Forest, Central Bangka Regency, Bangka Belitung. The research method used is observation, In-depth Interview and FGD (Focus Group Discussion) divided into small group discussion and final group discussion. The results show that the history of naming the Pelawan Forest comes from the tree of Pelawan (Tristaniopsis merguensis Griff.) that dominate the forest area. This forest is experiencing pros and cons before it is designated as Biodiversity Park of Central Bangka Regency. At the moment, the forest condition already has three functions, namely: biological resource conservation, sustainable development, and logistic support (research, education, and monitoring). Local wisdom community who are still awake and directly related to natural resources conservation Pelawan Forests can still be found as a tradition musung madu how to make a honey with sunggau to get the results in the form of honey of Apis dorsata (Wild Honey). In addition, people also still believe in the myth of growing mushrooms Pelawan (Heimioporus sp.) which can only grow on the host tree T. merguensis in the presence of thunderstorms. Therefore, the need to integrate the local wisdom of communities in support of conservation efforts by revitalization and the implementation of the local wisdom is given the basic law as the basis of power of the community, as well as the need for a review scientific research in support of local wisdom as environmental conservation efforts so as to give a positive impact to the lives of the community.
\end{abstract}

Keywords: Local wisdom, biodiversity, conservation, Pelawan forest.

Citation: Henri, Hakim, L., dan Batoro, J. (2018). Kearifan Lokal Masyarakat sebagai Upaya Konservasi Hutan Pelawan di Kabupaten Bangka Tengah, Bangka Belitung. Jurnal Ilmu Lingkungan, 16(1), 49-57,doi:10.14710/jil.16.1.49-57

\section{Pendahuluan}

Indonesia dikenal sebagai mega biodiversity country yang memiliki keanekaragaman hayati dan sumberdaya genetik yang sangat tinggi. Indonesia sebagai negara hotspot biodiversity, saat ini kurang memperhatikan pemanfaatan berkelanjutan dari keanekaragaman itu sendiri, sehingga ancaman terhadap kepunahan biodiversitas menjadi salah satu 
tertinggi di dunia (Sutarno \& Setyawan, 2015). Indonesia setiap tahun mengalami penurunan luasan tutupan lahan dari hutan primer tahunan mencapai 47.600 ha per tahun. Pada tahun 2012, peningkatan degradasi hilangnya hutan primer tahunan Indonesia lebih tinggi sebesar 0,84 Mha, jika dibandingkan di Brasil sebesar 0,46 Mha (Margono et al., 2014).

Bangka Belitung sebagai daerah provinsi kepulauan di Indonesia memiliki luas wilayah $\pm 81.725,14 \mathrm{Km}^{2}$, berbagai permasalahan lingkungan juga dialami dimana \pm 5.400 ha lahan terutama hutan beralih fungsi menjadi area pertambangan timah. Hal ini tentu dapat menyebabkan degradasi lingkungan yang timbul dari konversi hutan tersebut, termasuk degradasi lahan dan penyempitan lahan produktif masyarakat (Ginting et al., 2014). Sumber daya hutan yang terdegradasi dapat mengakibatkan perubahan struktur dan fungsi vegetasi suatu ekosistem serta berdampak juga terjadinya perubahan komposisi spesies flora maupun faunanya (Smith et al., 2014).

Degradasi sumberdaya hutan ini tentu memerlukan penanganan konservasi dalam menjaga kawasan hutan. Upaya konservasi diatur dalam Peraturan Menteri Lingkungan Hidup Republik Indonesia Nomor 03 tahun 2012 tentang Taman Keanekaragaman Hayati (Taman Kehati) yang berfungsi sebagai kawasan percadangan sumber daya alam hayati lokal di luar kawasan yang mempunyai fungsi konservasi secara in situ dan ex situ (BAPPENAS, 2016). Kerusakan lingkungan semakin hari semakin bertambah kompleks dan membutuhkan penanganan yang komprehensif sebagai upaya untuk merubah dan menyadarkan masyarakat akan pentingnya memelihara alam. Peran pemerintah terutama di Kabupaten Bangka Tengah-Bangka Belitung, saat ini telah menjadikan Taman Kehati Hutan Pelawan sebagai salah satu sumber percadangan plasma nutfah dan sebagai upaya untuk melestarikan serta konservasi tumbuhan lokal dari ancaman kepunahan (Buletin Bangka Tengah Membangun, 2015).

Kearifan lokal merupakan hal penting bagi masyarakat dalam beradaptasi dengan alam dan menjadi suatu warisan budaya dalam memanfaat dan mengelolah sumber daya alam dengan pengetahuan atau ide, norma adat, dan nilai budaya yang terkandung dalam konsep berfikir masyarakat (Nurdin \& Ng, 2013). Pengetahuan lokal dan praktik manajemen masyarakat sangatlah mendukung sebagai upaya konservasi lingkungan. Pengelolaan lingkungan melalui konsep pengetahuan ekologi tradisional dianggap berperan penting, dikarenakan lebih mengacu pada praktek, pengetahuan, nilai-nilai dan keyakinan individu dalam mengembangkan suatu lingkungan secara historis, konsepsi maupun persepsi oleh masyarakat setempat (Richeri et al., 2013).

Selain itu, konsep ini juga mempunyai peran serta dalam pengelolaan lingkungan secara berkelanjutan dan untuk membuat suatu kebijakan penting dalam kehidupan masyarakat (Ens et al., 2015). Peran serta masyarakat dalam upaya pengelolaan lingkungan yang berkelanjutan akan memberikan hasil positif di masa depan. Namun, dalam membudayakan masyarakat diperlukan ketelatenan dan juga kesabaran dalam membina, karena masyarakat tidak serta-merta dapat berubah secara drastis begitu saja. Proses yang dilakukan sangatlah panjang, serta perlu pendampingan yang terus menerus supaya masyarakat mempunyai pemahaman sesuatu dalam pengalamannya sehingga masyarakat dapat membudayakan dirinya dalam memanfaatkan suatu potensi ekosistem secara bijaksana (Rookes \& Wilson, 2000). Oleh karena itu, penelitian ini perlu dilakukan untuk mengkaji peran kearifan lokal masyarakat dari segi pengelolaan dan pengembangan kawasan hutan Pelawan dengan upaya mengedepankan konservasi lingkungan sehingga memberikan dampak positif bagi masyarakat secara berkelanjutan.

\section{Metode Penelitian}

\subsection{Waktu dan Lokasi Penelitian}

Penelitian ini dilaksanakan pada bulan Oktober 2016 sampai dengan Februari 2017. Penelitian lapangan dilaksanakan di Hutan Pelawan yang telah dijadikan sebagai Taman Kehati Hutan Pelawan, Desa Namang, Kecamatan Namang, Kabupaten Bangka Tengah, Provinsi Kepulauan Bangka Belitung.

Desa Namang memiliki potensi kawasan hutan yang telah dikembangkan menjadi Taman Keanekaragaman Hayati (Taman Kehati) Hutan Pelawan (Hutan Kalung; dalam bahasa lokal) dengan luas kawasan 47,4 Ha. Taman Kehati Hutan Pelawan termasuk kategori IV dalam daftar Perserikatan Bangsa-bangsa (PBB), dengan tujuan utama untuk menjaga, melestarikan dan memulihkan spesies dan habitat. Tujuan lainnya seperti: melindungi pola vegetasi biologi melalui pendekatan manajemen tradisional; untuk melindungi suatu fragmen habitat sebagai komponen strategi konservasi; mengembangkan kegiatan pendidikan publik; dan menyediakan saran penduduk lokal dalam berinteraksi untuk menjaga kondisi alam (Dudley, 2008).

\subsection{Metode}

Penelitian ini menggunakan metode wawancara mendalam (in-depth interview), yang dilakukan menggunakan beberapa informan yang berkompeten memberikan gambaran untuk mendapatkan data dan informasi yang melengkapi pertanyaan lebih detail (Primadesi, 2010). Wawancara yang ditujukan kepada informan dilakukan secara terpisah dengan informan lainnya untuk menghindari pengaruh secara langsung dari pendapat informan sebelumnya (Da Cunha \& De Albuquerque, 2006).

Selain itu, data juga diperoleh dengan menggunakan in-depth interview, terutama untuk data yang menyangkut kepatuhan atau nilai-nilai dan norma-norma yang berlaku di masyarakat lokal berkaitan dengan aspek kearifan lokal yang 
melatarbelakangi perilaku kolektif penduduk, terutama yang berkaitan dengan penerapan nilai, etika, estetika, dan ekonomi lokal. Data yang diperoleh dilanjutkan dalam diskusi FGD (Focus Group Discussion), tujuannya untuk memperoleh informasi dan masukan kepada peneliti mengenai hal-hal yang bersifat lokal dan spesifik (Wong, 2008). FGD pada penelitian ini juga menggunakan dua desain: 1) membentuk kelompok kecil dari hasil hipotesis dan analisis awal sebelum dikembangkan lebih terstruktur dan sistematis; dan 2) membentuk kelompok besar atau final discussion, sebagai tindak lanjut diskusi awal, untuk menemukan hasil yang diharapkan untuk menambah kekayaan dan kedalam informasi penelitian (Wilkinson, 1998).

\section{Hasil dan Pembahasan}

\subsection{Sejarah Hutan Pelawan}

Hutan Pelawan pada awal mulanya merupakan hutan primer yang dikenal masyarakat lokal sebagai hutan kalung yang banyak ditumbuhi berbagai jenis-jenis tumbuhan langka dan endemik lokal. Penamaan Hutan Pelawan berasal dari pohon pelawan yang banyak tumbuh pada area hutan tersebut. Pohon pelawan yang dikenal dengan nama ilmiah Tristaniopsis merguensis ini banyak dimanfaatkan oleh masyarakat lokal untuk kehidupan sehari-hari seperti untuk bahan bangunan, kayu api, dan sebagai tajar untuk perkebunan lada. T. merguensis seperti pada (Gambar 1) merupakan salah satu spesies dari famili Myrtaceae yang mempunyai tingkat penyebarannya cukup luas seperti di Myanmar bagian selatan, Thailand, Malaysia, Sumatera (terutama di Kepulauan Riau dan Kepulauan Bangka Belitung), Jawa Barat, dan Kalimantan (Sosef et al., 1998)

Hutan Pelawan termasuk kategori areal penggunaan lainnya (APL). Berdasarkan Peraturan Menteri Kehutanan Republik Indonesia Nomor 50 tahun 2009 menjelaskan bahwa APL merupakan areal bukan kawasan hutan, yang berarti bukan wilayah tertentu yang telah ditetapkan oleh pemerintah untuk dipertahankan keberadaanya sebagai hutan tetap. Sehingga berdampak terjadinya penebangan liar untuk diambil kayunya maupun pembukaan lahan oleh masyarakat lokal dalam kegiatan pertanian seperti perkebunan lada, hal ini terjadi sekitar tahun 1990-an. Aktivitas yang dilakukan masyarakat pada sebagian kawasan hutan ini tentu merubah struktur dan komposisi dari suatu ekosistem alaminya.
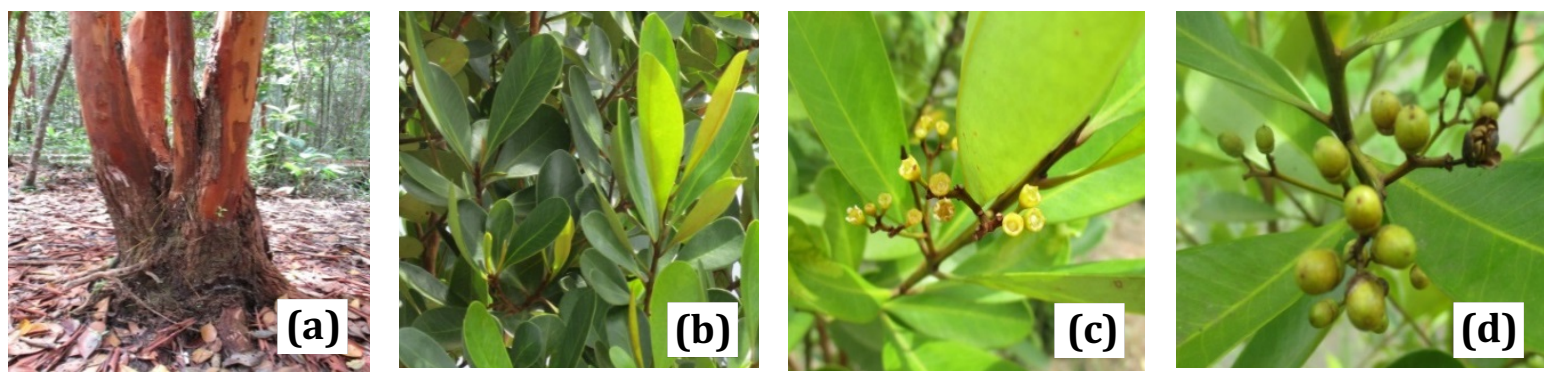

Gambar 1. Morfologi T. merguensis (a) Batang; (b) Daun; (c) Bunga; dan (d) Buah

Tahun 2000-an upaya pemulihan kembali Hutan Pelawan mengalami pro dan kontra. Masyarakat lokal sebagian tetap ingin memanfaatkan kembali hutan yang setelah lama ditinggalkan untuk dilakukan upaya pertambangan timah atau sering dikenal masyarakat sebagai tambang inkonvensional. Namun, upaya sebagian masyarakat yang ingin membuka hutan untuk pertambangan timah ditolak pada saat itu, dikarenakan akan memberi dampak yang besar lagi terhadap kerusakan lingkungan dan dianggap sia-sia upaya pemulihan ekosistem yang dilakukan selama ini. Penolakan ini sangat beralasan, karena kegiatan pertambangan seperti tambang timah ini sering menimbulkan dampak negatif. Menurut Brain (2017), kegiatan pertambangan dapat merusak suatu ekosistem dalam bentuk pencemaran air, tanah, dan udara, walaupun secara sistematik kegiatan pertambangan memberikan dampak terhadap mata pencaharian masyarakat. Selain itu juga, umumnya kegiatan pertambangan sering menimbulkan dampak sosial ekonomi masyarakat dan banyak menimbulkan konflik dalam kehidupan masyarakat lokal (Loayza \& Rigolini, 2016).
Saat ini Hutan Pelawan yang terkonversi ini telah mengalami suksesi berupa suksesi sekunder yang ditunjukkan dengan adanya perubahan kondisi hutan mulai dari awal menuju ke arah komunitas klimaks. Proses suksesi pada Hutan Pelawan hanya mengandalkan proses suksesi secara alami, dimana umumnya hanya mengandalkan tunas pohon dan pemencaran biji yang terbawa angin maupun hewan (Guevara et al., 2004). Perkembangan suksesi pada suatu ekosistem dapat berkembang secara spontan tanpa penanaman secara aktif melalui pembibitan dan akan mulai ditumbuhi vegetasi herba dan semak yang bertahan untuk waktu yang lama sebelum menjadi pohon (Kaligarič et al., 2006; Knapp et al., 2008).

Perkembangan konsep pengelolaan Hutan Pelawan menjadi signifikan setelah kawasan hutan tersebut dijadikan kawasan lindung pada tahun 2008-2009. Upaya memperkuat status konservasi terus dilakukan yang diinisiasi oleh pemerintah desa maupun pemerintah daerah guna melindungi jenisjenis flora dan fauna yang terancam punah, langka dari ekosistem hutan tersebut. Pada tahun 2013 hutan Pelawan dijadikan sebagai Taman Kehati 
berdasarkan SK Bupati Bangka Tengah Nomor 188.45/403/KLH/2013 tentang Penetapan Kawasan Kalung menjadi Taman Keanekaragaman Hayati Hutan Pelawan.

Setelah ditetapkan sebagai Taman Kehati, Hutan Pelawan memiliki 3 (tiga) fungsi yaitu: (1) fungsi konservasi sumber daya hayati; (2) fungsi pembangunan berkelanjutan; dan (3) fungsi logistic support (penelitian, pendidikan, dan monitoring). Konsep ini sejalan dengan prinsip pengembangan kawasan Cagar Biosfer, dimana berdasarkan program Man and Biosphere (MAB) Indonesia bahwa Cagar Biosfer sebagai suatu kawasan yang terdiri dari ekosistem asli, ekosistem unik dan ekosistem yang telah mengalami perubahan yang keseluruhan unsur alamnya dikelola bagi kepentingan konservasi, penelitian, pendidikan, dan pembangunan ekonomi berkelanjutan (Purwanto et al., 2013). Periode 2013 sampai dengan sekarang adalah tahap pengembangan potensi dimana salah satu unsur dari pembentukan Taman Kehati Hutan Pelawan diharapkan dapat memberikan manfaat ekonomi masyarakat secara langsung dengan memperhatikan aspek ekologi dan sosial masyarakat.

\subsection{Kearifan Lokal Masyarakat}

Masyarakat lokal Bangka yang ada di Desa Namang pada umumnya tetap menerapkan kearifan lokal sehari-harinya dalam menjaga dan melestarikan Hutan Pelawan. Upaya konservasi Hutan Pelawan ini dilakukan karena dalam suatu ekosistem hutan ini terdapat spesies kunci yaitu: berupa pohon pelawan (Tristaniopsis merguensis) yang termasuk dalam famili Myrtaceae. Spesies ini berperan penting sebagai inang untuk tumbuhnya jamur pelawan (Heimioporus sp.), sumber nektar untuk lebah madu liar raksasa (Apis dorsata), serta manfaat lainnya dalam mendukung pembangunan berkelanjutan dalam kehidupan masyarakat itu sendiri. Pembangunan berkelanjutan tidak hanya menitikberatkan sistem pendapatan ekonomi semata akan tetapi tetap mengedepankan sistem sosial budaya masyarakat dan upaya kelestarian lingkungan untuk masa depan (Akbarini, 2016).

Penerapan sistem pembangunan berkelanjutan pada masyarakat ini dapat diterapkan dengan cara mengintegrasi pengetahuan lokal masyarakat dan pengetahuan ilmiah dalam memanajemen lingkungannya. Hal tersebut diharapkan dapat menghasilkan pemahaman yang lebih baik dari sistem tertentu yang dimiliki oleh masyarakat (Taylor \& Loë, 2012). Pengetahuan lokal yang dipahami oleh masyarakat diterapkan berdasarkan pengalaman dan praktek dalam kehidupan seharihari yang menyesuaikan dengan ekosistem atau lingkungan lokal masyarakat tersebut (Ballard et al., 2008).

Kearifan lokal yang melekat pada masyarakat dalam menjaga lingkungan berdasarkan potensi hasil sumber daya alamnya, dapat menarik untuk di dalami lebih lanjut guna mempertahankan adat istiadat tanpa mengurangi upaya konservasi sehingga menjadi objek daya tarik tersendiri untuk dikembangkan sebagai produk atraksi ekowisata dalam meningkatkan pendapatan ekonomi masyarakat lokal. Berikut ini beberapa kearifan lokal masyarakat antara lain:

\subsubsection{Tradisi Musung Madu}

Kegiatan musung merupakan salah satu kegiatan mencari atau mengumpulkan lebah madu untuk mendapatkan hasil berupa air madu dan memisahkan lilinnya dengan teknik pengasapan guna mengusir lebah madu dari saranggnya dan biasanya dilakukan secara berkelompok, yang dimulai dengan cara tempat lebah madu bersarang seperti contoh pada Gambar 2a. Lebah madu dapat dibedakan menurut tempat madunya bersarang dibedakan menjadi dua jenis madu yaitu: jenis madu dahan dan jenis madu sunggau. Madu sunggau seperti pada Gambar 2b, dilakukan dengan cara pembuatan sunggau terlebih dahulu atau teknik tradisional masyarakat lokal.

Madu sunggau atau madu dahan ini dihasilkan oleh lebah madu liar raksasa (Apis dorsata) yang berhabitat di hutan dan sampai saat ini belum dapat dibudidayakan atau diternakkan seperti beberapa jenis lebah lain seperti: Apis meilifera, Apis cerena, Apis nigrocincta, dan lainnya. Apis dorsata umumnya membuat sarang dengan hanya satu sisiran yang menggantung di dahan dan ranting pohon yang mencapai 1x2 meter dengan estimasi hasil mencapai $20 \mathrm{~kg} /$ sarang. Spesies ini hanya berkembang di kawasan Asia sub-tropis maupun tropis, seperti Indonesia, Thailand, Philipina, India, Nepal, dan tidak ditemukan di luar kawasan Asia (Oldroyd \& Wongsiri, 2006).

Bentuk sunggau lebah madu yang dibuat sangatlah sederhana tanpa mengeksploitasi sumber daya alam secara berlebihan yaitu: dengan hanya dua batang kayu yang vertikal yang berfungsi untuk menyangga batang horizontal dengan tingkat kemiringan $15-30^{\circ}$. Kemiringan cabang dipilih agar sarang dapat menahan beban sarang madu yang berat. Sarang lebah madu liar ini terkonsentrasi di ujung sarang yang lebih tinggi. Satu hal penting dalam membuat sunggau adalah, pada bagian atas sungau dipastikan terbuka ke lingkungan luar atau tidak terhalang vegetasi tumbuhan disekitarnya. Tingkat keberhasilan sunggau cukup kecil berkisar $10-20 \%$ dan sangat bergantung pada musim bunga yang menjadi sumber nektar oleh Apis dorsata (Purwanto, 1999). Sarang lebah madu liar baik berupa madu dahan maupun madu sunggau yang siap untuk dipanen atau diambil airnya akan dilakukan pengambilan oleh masyarakat lokal yang dikenal dengan cara dipusung, yang dicirikan dengan membesarnya pada bagian kantung-kantung air madu tersebut. Peralatan musung madu ini dikenal masyarakat atau sering disebut nyenyamu. Nyenyamu tersebut pada umumnya dibuat oleh masyarakat menggunakan ranting-ranting kayu kering yang ada 
Henri., Hakim, L, dan Batoro, J. (2018). Kearifan Lokal Masyarakat sebagai Upaya Konservasi Hutan Pelawan di Kabupaten Bangka Tengah, Bangka Belitung . Jurnal IImu Lingkungan, 16(1), 49-57, doi: 10.14710/jil.16.1.49-57

disekitar hutan dengan perpaduaan berbagai jenis dedaunan, kemudian ranting dan dedaunan yang dililit menggunakan tali ketakung (Nepenthes sp.) maupun jenis-jenis akar kayu lainnya yang dapat digunakan. Kegiatan musung menggunakan nyenyamu, dilakukan dengan cara membakar bagian yang terkecil sampai yang terbesar dari bentuk
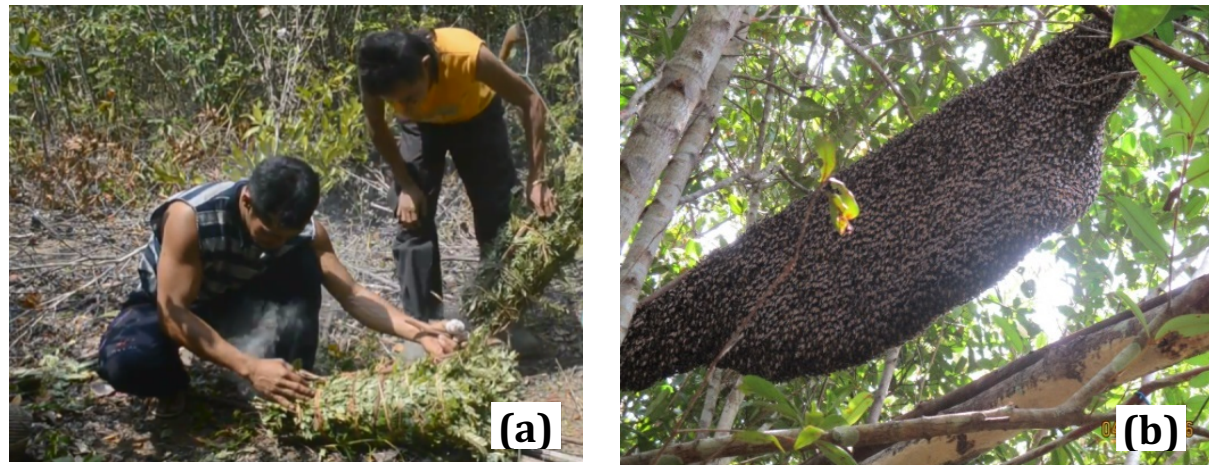

Gambar 2. Musung madu (a) Persiapan musung madu; (b) Bentuk madu sunggau

Masyarakat lokal pada saat ini masih menerapkan etika dalam sistem sosial budaya mereka, dimana sunggau yang sudah terpasang tidak boleh diambil secara sembarangan apalagi bukan hak milik orang tersebut. Hal itu tidak boleh dilakukan karena pada umumnya setiap sunggau yang telah dipasang tanda tertentu disertai dengan mantramantra tertentu. Kepercayaan dalam masyarakat lokal Bangka, apabila madu yang didapatkan bukan merupakan madu hasil memasang sunggau sendiri nyenyamu tersebut sampai merata, sehingga akan mengeluarkan asap tebal. Kegiatan pengasapan atau dikenal dengan musung ini secara kearifan lokal masyarakat setempat, berperan untuk mengusir lebah madu keluar meninggalkan sarangnya.

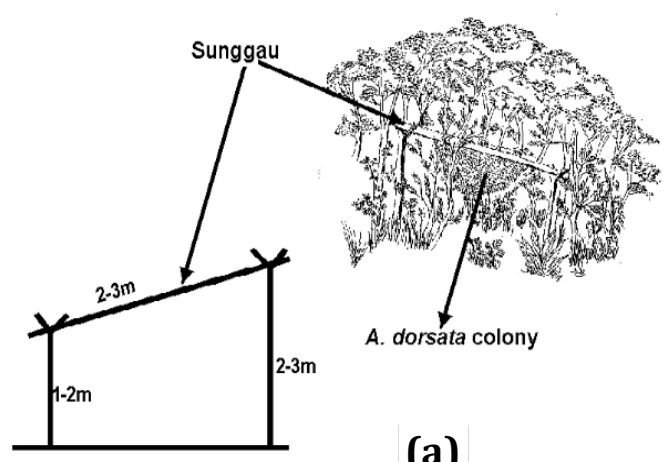

melainkan mengambil madu dari sunggau orang lain, maka hasil madu tersebut akan membawa malapetaka dan penyakit bagi orang tersebut. Kearifan lokal masyarakat tersebut masih tetap bertahan dikarenakan masyarakat mempercayai bahwa hal tersebut merupakan suatu nilai budaya yang harus diyakini dan harus dijunjung tinggi kepatuhannya sebagai suatu aturan yang berfungsi sebagai sarana untuk mewujudkan perilaku masyarakat lokal tersebut (Elvian, 2009).

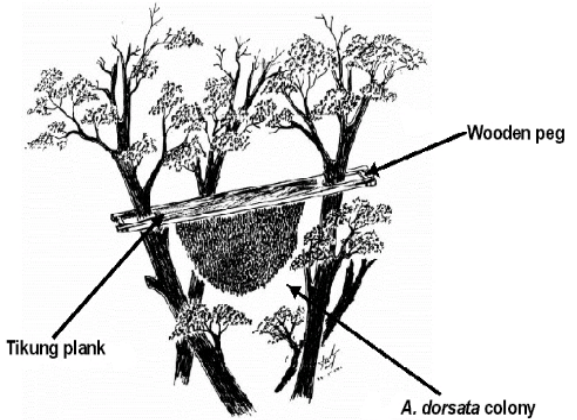

(b)

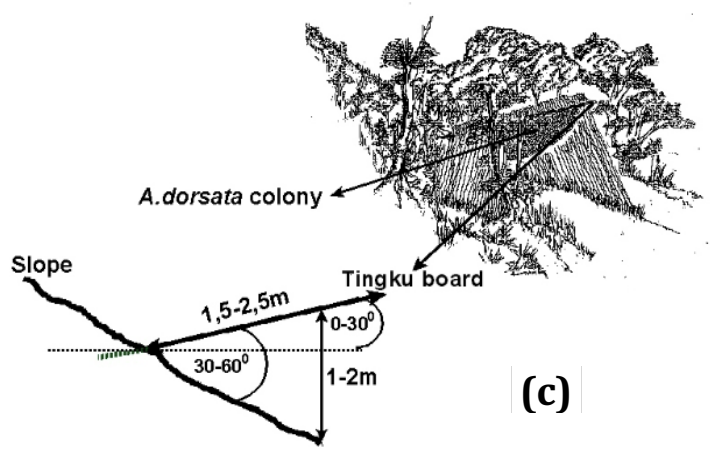

Gambar 3. Teknik tradisional sarang lebah madu (a). Sunggau; (b) Tikung; (c) Tingku

Aspek keberlanjutan suatu kearifan lokal seperti kegiatan musung madu oleh beberapa kelompok masyarakat lokal tetap terjaga. Pulau Bangka dan
Pulau Belitung sudah sejak tiga dekade yang lalu menggunakan teknik sunggau untuk mendapatkan lebah madu liar (Apis dorsata). Pada beberapa daerah 
lainnya mempunyai prinsip yang hampir sama dengan teknik sunggau, seperti halnya di daerah sungai Kapuas, Kalimantan Barat menggunakan teknik tikung semenjak satu abad yang lalu. Selain itu, teknik tradisional untuk memdapatkan lebah madu juga terdapat pada masyarakat lokal di Desa Kelei, Sulawesi Tengah sejak 1930-an dengan menggunakan teknik tingku. Perbedaan ketiga teknik tradisional yang tersaji pada (Gambar 3) tersebut adalah berupa kondisi, topografi daerah, dan cara memasangnya (Hadisoesilo, 2001).

Lebah madu liar (Apis dorsata) ini umumnya hanya akan keluar dari sarangnya untuk mencari nektar, polen, propolis dan air. Selain itu, madu ini sangat banyak memiliki manfaat dikarenakan memiliki kandungan berbagai senyawa aktif biologis seperti flavonoid, vitamin, antioksidan seperti hidrogen peroksida $\left(\mathrm{H}_{2} \mathrm{O}_{2}\right)$ (Mohammadzadeh et al., 2007), kandungan senyawa fenolik seperti flavonoid yang ada pada madu ini dapat menginduksi kematian sel dari berbagai jenis sel kanker (Chang et al., 2008), komposisi lain seperti asam amino, asam glukon, protein dan vitamin dapat menghambat pertumbuhan sel tumor paru-paru (Takeuchi et al., 2011).

\subsubsection{Mitos Tumbuh Jamur Pelawan}

Berdasarkan wawancara dan pengamatan di lapangan diketahui jamur pelawan atau yang lebih dikenal masyarakat lokal yaitu kulat pelawan merupakan jamur pangan yang bernilai ekonomis tinggi dengan harga 2 juta/kg jamur kering. Mahalnya harga jual ini disebabkan karena faktor tumbuh jamur susah untuk dibudidayakan dan hanya mengandalkan pertumbuhan alami di sekitar pohon

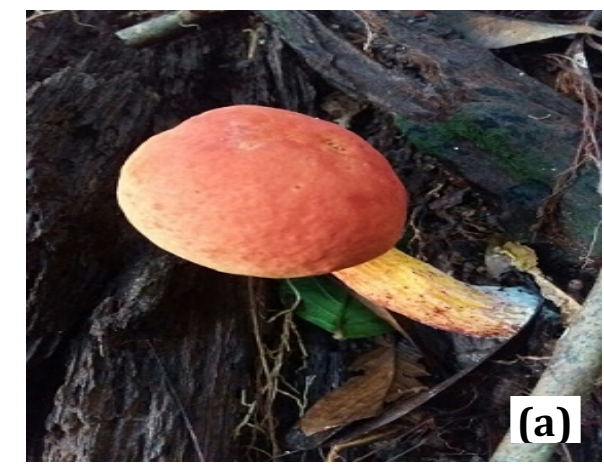

Gambar 4. Jamur Pelawan (Heimioporus sp.) (a) Individu jamur; (b) Tempat tumbuh jamur

Berdasarkan Henkel et al. (2002) dan Halling et al. (2008), jamur pelawan yang berasal dari genus Heimioporus ini termasuk bagian dari famili Boletaceae yang merupakan jamur ektomikoriza. Jamur ektomikoriza ini sendiri merupakan jamur yang hanya dapat tumbuh dengan cara bersimbiosis dengan inang tumbuhan berkayu dengan beberapa famili tumbuhan antara lain: Betulaceae, Caesalpiniaceae, Casuarinaceae, Dipterocarpaceae, Ericaceae, Fagaceae, Mimosaceae, Myrtaceae, pelawan (T. merguensis) sebagai inangnya seperti contoh pada Gambar 4b. Jamur pelawan ini merupakan jamur dari genus Heimioporus, yang ditandai dengan ormentasi spora yang unik dimana dinding basidiosporanya berlubang atau ornamen alveolat-retikulat sampai retikulat (Halling et al., 2008) seperti contoh pada Gambar 4a. Berdasarkan karakter morfologi dan molokulernya, jamur pelawan yang termasuk bagian anggota genus Heimioporus ini sangat mirip dan memiliki kekerabatan dengan Heimioporus retisporus dengan homologi di bawah 90\%, akan tetapi juga dapat dikategorikan spesies baru karena memiliki perbedaan morfologi spora dan bentuk beberapa komponen pelisnya (Tasuruni, 2012).

Menurut kepercayaan masyarakat setempat, munculnya jamur ini terjadi pada setelah kemarau yang dikuti dengan hujan yang disertai dengan petir. Selain itu juga, bahwa musim hujan memberikan kesempatan pada semua tumbuhan untuk menyerap air lebih banyak dan menyediakan kebutuhan yang cukup bagi jamur untuk tumbuh. Umumnya, jamur ini tumbuh dua kali dalam setahun pada bulan Juli dan Oktober sesuai dengan kondisi cuaca, sehingga jamur ini tidak dapat dijumpai setiap waktu. Beberapa hari setelah adanya petir di musim hujan, jamur ini (tubuh buah) akan muncul di permukaan tanah dan hanya bertahan selama tiga hari setelah tumbuh, setelah itu jamur akan mengalami pembusukan. Massyarakat menyakini tumbuhnya jamur ini hanya terdapat pada pohon pelawan ( $T$. merguensis) dan sampai saat ini jamur pelawan belum bisa dikembangbiakkan, walaupun telah dilakukan kajian mengenai ekologi jamur tersebut.

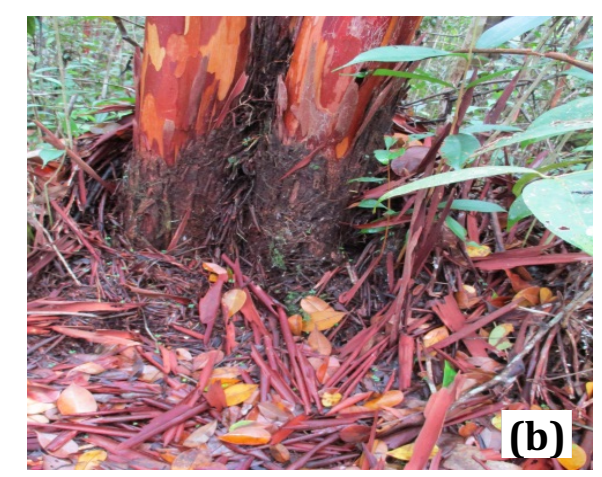

Pinaceae, dan Salicaceae. Jamur ini menghasilkan tubuh buah di bawah tanah dan mengandalkan hewan terutama mamalia yang menggali untuk penyebaran sporanya.

Jamur Pelawan juga merupakan salah satu jamur pangan yang tinggi protein dan rendah lemak sehingga banyak dimanfaatkan oleh masyarakat di Pulau Bangka khususnya di Desa Namang sebagai bahan menu tradisionalnya dan masyarakat menyimpannya dalam bentuk kering untuk dapat 
Henri., Hakim, L, dan Batoro, J. (2018). Kearifan Lokal Masyarakat sebagai Upaya Konservasi Hutan Pelawan di Kabupaten Bangka Tengah, Bangka Belitung . Jurnal IImu Lingkungan, 16(1), 49-57, doi: 10.14710/jil.16.1.49-57

dikonsumsi sewaktu-waktu. Jamur ini juga memiliki kapasitas sebagai sumber potensial pangan fungsional karena memiliki kandungan mineral, serat pangan, biotin, dan vitamin $\mathrm{C}$ yang tinggi untuk dapat membantu mencukupi kebutuhan tubuh, serta memiliki kemampuan yang baik sebagai antioksidan. Jamur pelawan mengandung 7 asam amino esensial antara lain: treonin, valin, metionin, isoleusin, leusin, fenilalanin, dan lisin. Kandungan biotin dan vitamin C dari jamur ialah 27,35 $\mu \mathrm{g} / 100 \mathrm{~g}$, dan 12,46 mg/100g. Hasil analisis kandungan mineral menunjukkan bahwa untuk setiap $1 \mathrm{~kg}$ jamur pelawan mengandung $31,60 \mathrm{~g}$ kalium $(\mathrm{K}) ; 5,80 \mathrm{~g}$ fosfor $(\mathrm{P}) ; 0,52 \mathrm{~g}$ natrium (Na); 14,88 mg kalsium (Ca); 62,52 mg zat besi (Fe); dan 67,86 mg seng (Zn). Selain itu, jamur pelawan kandungan antioksidan yang terdiri atas komponen fenolik sebesar 4,77 mg GAE/g, sedangkan pada komponen pigmen dan antioksidan lainnya seperti $\beta$ karoten dan likopen ialah 15,37 $\mu \mathrm{g} / \mathrm{g}$ dan $6,34 \mu \mathrm{g} / \mathrm{g}$ (Rich, 2011).

\subsection{Integrasi Konservasi secara Berkelanjutan}

Pengetahuan masyarakat lokal dapat dijadikan sebagai salah satu upaya dalam mendukung upaya integrasi konservasi dan pengembangan potensi sumber daya alam hayati dan ekosistem di Hutan Pelawan. Masyarakat lokal harus dijadikan subjek dalam pengelolaan sumber daya alam hayati dan ekosistemnya sehingga pemanfaatan sumber daya alam dalam upaya pengembangan sebagai objek wisata dapat dilakukan secara berkelanjutan untuk kepentingan bersama. Oleh karena itu, diperlukan beberapa strategi dan upaya untuk memperkuat pengembangan potensi Hutan Pelawan dengan mengedepankan kearifan lokal masyarakat dalam mendukung konservasi lingkungan.

Masyarakat lokal di Desa Namang memiliki pandangan bahwa Hutan Pelawan berupa alam dan lingkungannya memiliki sejarah kehidupan yang cukup panjang hingga menghasilkan suatu kepercayaan, kebudayaan dan tradisi sehingga bernilai positif dalam mendukung pengembangan objek wisata saat ini. Untuk menjaga kelestarian sumber daya alam hayatinya masyarakat telah memiliki kearifan lokal cara pemanfaatan dan pengelolaannya seperti tradisi musung madu. Tradisi ini tidak mengeksploitasi sumber daya alamnya secara berlebihan dan justru dapat menjadi objek daya tarik pengembangan potensi wisata.

Kearifan lokal masyarakat yang ada tersebut tentu menjadi modal penting dalam mendukung program ekowisata Hutan Pelawan. Hal ini relevan dengan potensi sumber daya hayati Hutan Pelawan yang dapat dikembangkan sebagai objek daya tarik ekowisata (Henri et al., 2017a). Potensi flora dan fauna yang tinggi dan khas menjadi pendukung dan

\section{DAFTAR PUSTAKA}

Akbarini, D. 2016. Pohon pelawan (Tristaniopsis merguensis): Spesies kunci keberlanjutan Taman Keanekaragaman Hayati Namang-Bangka Tengah. AlKauniyah Jurnal Biologi. 9(1): 66-73. daya tarik tersendiri bagi kawasan Hutan Pelawan untuk dapat dijadikan sebagai kawasan ekowisata yang berpotensi menarik minat wisatawan dan dapat mendukung peningkatan ekonomi masyarakat lokal (Henri et al., 2017b). Masyarakat sendiri dapat memainkan peran yang lebih penting sebagai promotor pariwisata, penguna, dan pelayan sumber daya (Tsaur et al., 2006). Pengetahuan masyarakat terhadap perencanaan dan pengembangan ekowisata yang bersifat multidimensional tentu dapat memberikan nilai kepuasan wisatawan dengan melibatkan masyarakat dalam aktivitas sehari-hari dalam bentuk perilaku terhadap lingkungan, sehingga diharapkan berkontribusi bagi para pemangku kepentingan pengembangan ekowisata (Chiu et al., 2014).

Oleh karena itu, dalam mengintegrasikan konservasi Hutan Pelawan secara berkelanjutan, maka kearifan lokal masyarakat tersebut mempunyai peran penting dalam mewujudkannya. Adapun beberapa cara dalam mewujudkannya yaitu: (1) kearifan lokal masyarakat yang ada saat ini sangat perlu direvitalisasi dan direaktualisasi; (2) kearifan lokal perlu diberi payung hukum sebagai dasar kekuatan agar dapat terjaga dan berdampak positif pada lingkungan kehidupan masyarakat; dan (3) perlunya dukungan penelitian untuk menyajikan bukti ilmiah atas dampak positif dari kearifan lokal dalam pengelolaan dan konservasi sumber daya alam hayatinya terutama pada Hutan Pelawan ini. Kearifan lokal masyarakat tersebut dapat dipertahankan dengan cara membentuk masyarakat hukum adat yang diatur oleh undang-undang dalam rangka memberi penguatan terhadap pengakuan dan perlindungan atas hak-hak masyarakat hukum adat pada saat mengakses atau memanfaatkan sumber daya alam (Sabardi, 2013).

\section{Kesimpulan}

Hutan Pelawan menjadi berpotensi dikarenakan dalam pengelolaannya masih menerapkan kearifan lokal masyarakat setempat dalam mendukung upaya konservasi lingkungan. Kehidupan masyarakat desa sangat erat kaitannya dengan upaya konservasi, hal ini dapat dilihat dari kearifan lokal seperti: kegiatan tradisi musung madu dengan cara membuat sunggau terlebih dahulu dan mitos tumbuhnya jamur pelawan (Heimioporus sp.) yang masih dipercayai masyarakat lokal hanya dapat tumbuh pada inang pohon pelawan (Tristaniopsis merguensis) disaat datangnya hujan petir. Perlunya mengintegrasikan kearifan lokal dan upaya konservasi sumberdaya alam dikarenakan merupakan bagian dari konsep berfikir masyarakat mengenai lingkungan secara holistik, sehingga menjadi modal pemahaman terhadap kualitas sumberdaya hayati secara berkelanjutan.

Ballard, H. L., Fernandez-Gimenez, M. E., and Sturtevant, V. E. 2008. Integration of local ecological knowledge and conventional science: a study of seven community-based forestry organizations in the USA. Ecology and Society. 13(2): 37-45. 
BAPPENAS [Badan Perencanaan Pembangunan Nasional]. 2016. Indonesian biodiversity strategy and action plan 2015-2020. Kementerian Perencanaan Pembangunan Nasional/BAPPENAS. Jakarta. http://www.bappenas.go.id. [27 April 2016].

Brain, K. A. 2017. The impacts of mining on livelihoods in the Andes: A critical overview. Extractive Industries and Society. 1-9.

Buletin Bangka Tengah Membangun. 2015. Hutan hayati untuk warisan anak negeri. Bangka Tengah: Dinas Perhubungan, Komunikasi dan Informatika, Kabupaten Bangka Tengah. http://www.bangkatengah.go.id. [27 April 2016].

Chang, H., Mi, M., Ling, W., Zhu, J., Zhang, Q., Wei, N., and Yuan, J. 2008. Structurally related cytotoxic effects of flavonoids on human cancer cells in vitro. Archives of Pharmacal Research. 31(9): 1137-1144.

Chiu, Y. T. H., Lee, W. I., and Chen, T. H. 2014. Environmentally responsible behavior in ecotourism: Antecedents and implications. Tourism Management. 40: 321-329.

Da Cunha, L. V. F. C., \& De Albuquerque, U. P. 2006. Quantitative ethnobotany in an Atlantic Forest fragment of Northeastern Brazil- Implications to conservation. Environmental Monitoring and Assessment. 114(1-3): 1-25.

Elvian, A. 2009. Musung madu. http://www. wisatadanbudaya.blogspot.co.id. [21 Februari 2017]

Ens, E. J., Pert, P., Clarke, P. A., Budden, M., Clubb, L., Doran, B., and Wason, S. 2015. Indigenous biocultural knowledge in ecosystem science and management: Review and insight from Australia. Biological Conservation. 181: 133-149.

Ginting, P., Budi, R., and Khalid, K. 2014. Grim portrait of Bangka Belitung tin mining: Demanding global, national and local responsibility to restore Bangka Belitung islands following negative tin mining impacts. WALHI in collaboration with Milieudefensie. Amsterdam. htttp://www.milieudefensie.nl. [19 Mei 2016].

Guevara, S., Laborde, J., and Rios, G. S. 2004. Rain forest regeneration beneath the canopy of fig trees isolated in Pastures of Los Tuxtlas, Mexico. Biotropica. 36(1): 99-108.

Hadisoesilo, S. 2001. Diversity in traditional techniques for enticing Apis dorsata colonies in Indonesia. In Proceedings of the $37^{\text {th }}$ International Congress. Apimondia, Durban.

Halling, R. E., Osmundson, T. W., Neves, M., and Lumbsch, H. T. 2008. Pacific boletes: Implications for biogeographic relationships. Mycological Research, 112: 437-447.

Henkel, T. W., Terborgh, J., and Vilgalys, R. J. 2002. Ectomycorrhizal fungi and their leguminous hosts in the Pakaraima Mountains of Guyana. Mycological Research. 106(5): 515-531.

Henri, Hakim, L., and Batoro, J. 2017a. Ecotourism Development Strategy of Pelawan Forest in Central Bangka , Bangka Belitung. Journal of Indonesian Tourism and Development Studies. 5(3): 145-154.

Henri, Hakim, L., and Batoro, J. 2017b. The Potential of Flora and Fauna as Tourist Attractions in Biodiversity Park of Pelawan Forest, Central Bangka. Biosaintifika: Journal of Biology \& Biology Education, 9(2): 240-247.

IUCN [International Union for Conservation of Nature and
Natural Resources]. 2008. Guidelines for applying protected area management categories. Gland, Switzerland: IUCN. https://books.google.co.uk. [27 April 2016]

Kaligarič, M., Culiberg, M., and Kramberger, B. 2006. Recent vegetation history of the North Adriatic grasslands: Expansion and decay of an anthropogenic habitat. Folia Geobotanica. 41(3): 241-258.

Knapp, A. K., Briggs, J. M., Collins, S. L., Archer, S. R., BretHarte, M. S., Ewers, B. E., and Cleary, M. B. 2008. Shrub encroachment in North American grasslands: shifts in growth form dominance rapidly alters control of ecosystem carbon inputs. Global Change Biology. 14: 615-623.

Loayza, N., and Rigolini, J. 2016. The Local Impact of Mining on Poverty and Inequality: Evidence from the Commodity Boom in Peru. World Development. 84: 219-234.

Margono, B. A., Potapov, P. V, Turubanova, S., Stolle, F., and Hansen, M. C. 2014. Primary forest cover loss in Indonesia over 2000-2012. Nature Climate Change: 4(6): 1-6.

Mohammadzadeh, S., Sharriatpanahi, M., Hamedi, M., Amanzadeh, Y., Sadat Ebrahimi, S. E., \& Ostad, S. N. 2007. Antioxidant power of Iranian propolis extract. Food Chemistry. 103(3): 729-733.

Nurdin, B. V., and Ng, K. S. F. 2013. Local Knowledge of Lampung People in Tulang Bawang: An Ethnoecological and Ethnotechnological Study for Utilization and Conservation of Rivers. Procedia Social and Behavioral Sciences. 91: 113-119.

Oldroyd, B. P., and Wongsiri, S. 2006. Asian Honey Bees : Biology, Conservation, and Human Interactions. The Quarterly Review of Biology. 81: 408.

Primadesi, Y. 2010. Peran masyarakat lokal dalam usaha pelestarian naskah-naskah kuno Paseban. Jurnal Bahasa dan Seni. 11(2): 120-127.

Purwanto, D. B. 1999. Some observations on bee keeping management with Apis dorsata in Belitung, South Sumatra, Indonesia. [thesis]. Faculty of Forestry and Ecology. Universitat Gottingen. Germany.

Purwanto, Y., Prasetya, B., and Ningrum, C. 2013. Pengelolaan terpadu dan berkelanjutan Cagar Biosfer Tanjung Puting. ICIAR-LIPI. Bogor.

Rich, R. 2011. Kajian terhadap jamur pangan pelawan (Boletus sp.) khas Indonesia sebagai sumber potensial pangan fungsional. [skripsi]. Fakultas Teknologi Pertanian, Institut Pertanian Bogor. Bogor.

Richeri, M., Cardoso, M. B., and Ladio, A. H. 2013. Soluciones locales y flexibilidad en el conocimiento ecol??gico tradicional frente a procesos de cambio ambiental: Estudios de caso en Patagonia. Ecologia Austral. 23(3): 184-193.

Rookes, P., and Wilson, J. 2000. Perception: Theory, development, and organisation. London and Pliladelphia: Routledge.

Sabardi, L. 2013. Konstruksi makna yuridis masyarakat hukum adat dalam pasal 18B UUDN RI tahun 1945 untuk identifikasi adanya masyarakat hukum adat. Jurnal Hukum dan Pembangunan. 2: 170-196.

Smith, A. M. S., Kolden, C. A., Tinkham, W. T., Talhelm, A. F., Marshall, J. D., Hudak, A. T., and Gosz, J. R. 2014. Remote sensing the vulnerability of vegetation in natural terrestrial ecosystems. Remote Sensing of Environment. 154: 322-337.

Sosef, M. S. ., Hong, L. ., \& Prawirohatmodjo, S. 1998. Timber 
Henri., Hakim, L, dan Batoro, J. (2018). Kearifan Lokal Masyarakat sebagai Upaya Konservasi Hutan Pelawan di Kabupaten Bangka Tengah, Bangka Belitung . Jurnal IImu Lingkungan, 16(1), 49-57, doi: 10.14710/jil.16.1.49-57

trees: Lesser-know timbers. Backhyus Publisher/Plant Resources of South-East Asia (PROSEA). Leiden.

Sutarno, and Setyawan, A. D. 2015. Biodiversitas Indonesia: Penurunan dan upaya pengelolaan untuk menjamin kemandirian bangsa. Pros Sem Nas Masy Biodiv Indon. 1(1): 1-13.

Takeuchi, M., Fukuda, M., Kobayashi, K., Hirono, Y., Miyagawa, M., Ishida, T., and Pinkerton, K. E. 2011. Jungle honey enhances immune function and antitumor activity. Evidence-Based Complementary and Alternative Medicine. 1-8.

Tasuruni, D. 2012. Analisis morfologi dan sekuens ITS rDNA jamur edibel ektomikoriza pelawan dan struktur ektomikorizanya. [tesis] Sekolah Pascasarjana, Institut Pertanian Bogor. Bogor.

Taylor, B., and Loë, R. C. D. 2012. Geoforum Conceptualizations of local knowledge in collaborative environmental governance. Geoforum, 43(6): 1207-1217.

Tsaur, S. H., Lin, Y. C., \& Lin, J. H. (2006). Evaluating ecotourism sustainability from the integrated perspective of resource, community and tourism. Tourism Management. 27(4): 640-653.

Wilkinson, S. 1998. Focus group methodology: a review. International Journal of Social Research Methodology. 1(3): 181-203.

Wong, L. P. 2008. Focus group discussion: a tool for health and medical research. Singapore Medical Journal. 49(3): 256-260 